Rok XVI (2021) | 1 (31) | S. 143-156

https://doi.org/10.12797/LV.16.2021.31.11

Dorota Rojszczak-Robińska •

Uniwersytet im. Adama Mickiewicza, Poznań

dorroj@amu.edu.pl

\title{
O KSZTAŁTOWANIU SIĘ STAROPOLSKIEJ FORMUŁY JAKOBY RZEKŁ ${ }^{1}$
}

Słowa klucze: apokryf, formuliczność, komentarz, staropolszczyzna, styl religijny Keywords: apocrypha, formulaicity, commentary, Old Polish language, religious style

Z polskiej literatury średniowiecznej zachowało się niewiele tekstów, głównie religijnych: tłumaczeń wybranych ksiąg i fragmentów Biblii, kazań, pieśni, a także sporo glos do łacińskich tekstów różnego typu (zob. np. Belcarzowa 1981-2001; Leńczuk 2013). Na tym tle wyróżnia się grupa tekstów, powszechnie zwanych - za Marią Adamczyk (1980) - staropolskimi narracjami biblijno-apokryficznymi. To duży zbiór (łącznie ponad 2000 kart rękopisów i starodruków). W jego skład wchodzi siedem tekstów zachowanych w rękopisie (Rozmyślanie przemyskie, Karta Rogawskiego, List Lentulusa, Rozmyślania dominikańskie, Sprawa chędoga, Ewangelia Nikodema, Historyja Trzech Kroli) oraz dwa druki (Żywot Pana Jezu Krysta i Żywot świętej Anny). Utwory te różnią się poziomem zaawansowania przekazywanych treści, głównie teologicznych. Mimo że są to „z założenia” narracje o życiu Jezusa i Maryi, a ich celem "gatunkowym” jest uzupełnienie miejsc pustych Pisma Świętego (zob. np. Adamczyk 1980; Starowieyski 2015), w wielu fragmentach widać refleksję autorów nad tekstem Biblii. Częste są komentarze, dopowiedzenia, uzupełnienia

1 Badania realizowane w ramach grantu Narodowego Centrum Nauki (projekt nr 2017/26/E/HS2/ HS2/ooo83) pt. „Początki języka polskiego i kultury religijnej w świetle średniowiecznych apokryfów Nowego Testamentu. Uniwersalne narzędzie do badań polskich tekstów apokryficznych", pod kierunkiem Doroty Rojszczak-Robińskiej. 
treści biblijnych. Ewangelie (jeśli nie liczyć przypowieści) niewiele zachowały rozmów, które z pewnością toczyli ze sobą bohaterowie. Apokryfy tę lukę uzupełniają.

W staropolskich apokryfach zwraca uwagę duża liczba zdań wprowadzanych przez jakoby rzekt. Bardzo często pojawiają się parafrazy słów postaci biblijnych, najczęściej Jezusa, funkcjonujące jak rodzaj komentarza. Takie wypowiedzenia wprowadzane są jak mowa niezależna, właśnie przez frazę jakoby rzekł. Apokryfista sugerował, że to słowa danej postaci, ale jednocześnie zaznaczał swój dystans.

Zdania takie zauważyła już Joanna Sobczykowa w komentarzach biblijnych Jakuba Wujka: „W celu pokazania czy raczej dokładniejszego obejrzenia obcej konstrukcji stosuje parafrazy poprzedzone formułą wprowadzającą jakoby rzekl" (Sobczykowa 2001: 39). Pojawiły się one w polszczyźnie jednak dużo wcześniej.

Celem artykułu jest analiza właśnie tych konstrukcji, tj. zdań-parafraz wprowadzanych przez jakoby rzekł, w średniowiecznych polskich apokryfach, ich pochodzenia i funkcji, jaką pełnią.

Frazę jakoby rzekł będę nazywać formułą. Termin ten rozumiem za Magdaleną Pudą-Blokesz (2009) jako ustalony konwencjonalny ciąg wyrazowy (czyli inaczej niż np. badacze oralności, jak Albert B. Lord, Milman Parry czy Jerzy Bartmiński). Ważną cechą formuł jest powtarzalność i jednostajność, na co zwracała uwagę już Irena Bajerowa (1994: 15), która formułowość wskazała jako jedną z podstawowych cech stylu religijnego.

W polszczyźnie wyjaśnienia wprowadzane przez jakoby rzekł pojawiają się nie tyle w samym tekście biblijnym (czy raczej jego przekładzie), co w jego „opracowaniu”. Inna jest bowiem najczęściej ich funkcja. Magdalena Puda-Blokesz wśród formuł biblijnych wyróżnia formuły sprawcze, „formuły o doniosłości religijno-prawnej" (2009: 43), rytualne i grzecznościowe. Każdą z nich możemy spotkać też w staropolskich apokryfach. Powszechne są formuły sprawcze, np.:

Dziewko, mowię tobie: Wstań (ŻPJK 27v/25-26²).

Nieco rzadsze są formuły prawne:

bo nam tako przykazano w naszym zakonie: Będzieli kto uwłoczył czci Bożej, śmiercią złą niechaj umrze (ŻPJK 89r/10-11).

W scenach z procesu pojawiają się formuły rytualne:

I rzekli Żydowie: „Żyw Bog, iże nie wierzemy wam” (EN 272v/20-21);

Przed wszemi świadkami mam słońce i miesiąc, iż ja na tem człowiece winy śmiertelnej najć nie mogę (RD 134/5-7).

2 Jeśli nie zaznaczam inaczej, wszystkie transkrypcje są autorstwa zespołu działającego pod moim kierownictwem i zostały przygotowane na potrzeby grantu (zob. przypis 1). Dostępne są na stronie: apocrypha.amu.edu.pl. Cytaty lokalizuję, podając skrót tytułu, numer karty i, po ukośniku, zakres wersów. 
Podobnie jak w Biblii, w staropolskich apokryfach znajdziemy również językowe formuły grzecznościowe, w dużej części także przejmowane za źródłem kanonicznym:

A obrociwszy sie ku niewieście, rzekł: „펴i w pokoju” (ŻPJK 28r/38-39).

Niektóre z tych formuł (jak ostatnia - według Pudy-Blokesz (2009: 47) „wyrażająca chęć uniknięcia lub przeciwstawienia się czyjejś interwencji”) pojawiają się wyłącznie w miejscach przejętych za Pismem Świętym, inne stosowane są swobodnie, niezależnie od źródła. Odnosi się wrażenie, że różny jest stopień przyswojenia tychże, szczególnie te właściwe dla etykiety Bliskiego Wschodu mogą być obce 3 .

Ich obecność nie dziwi - Biblia jest podstawowym źródłem nie tylko treści, ale i stylu staropolskich apokryfów (zob. np. Rojszczak-Robińska 2014). W samym Piśmie Świętym brak jest formuł objaśniających - Biblia jest przecież ich obiektem, tekstem objaśnianym. A staropolskie apokryfy nie tylko uzupełniają opowieści biblijne, ale i komentują ich treść. Bardzo często komentarze są związane z czasem i miejscem poszczególnych wydarzeń ${ }^{4}$. Równie ważne są przytaczane wypowiedzi bohaterów. Formuła jakoby rzekt jest „zarezerwowana” do komentowania dialogu, wypowiedzi poszczególnych postaci. Ledwie w kilku miejscach używa się tej formuły bez cytowania samej wypowiedzi parafrazowanej (zob. np. RP 668/9-12).

Najstarsze użycia frazy jakoby rzekł są notowane na wiek XV, a ich rozkwit przypada na XVI w. SStp w haśle JAKOBY jeszcze nie notuje tej konstrukcji składniowej. Przykłady użycia umieszczono pod znaczeniem „w zdaniu złożonym wprowadza zdanie sposobowe ‘jak, w jaki sposób’ a. porównawcze” (SStp) ${ }^{5}$. W zeszycie 48, który pojawił się 17 lat później, dostrzeżono już tę funkcję. W haśle RZEC czytamy: „ jakoby rzekł(a), rzekli, wyjątkowo rz(e)kąc: wprowadza wypowiedzenie wyjaśniające treść wcześniejszego tekstu 'innymi słowy, to znaczy, czyli, id est”' (SStp). Co interesujące, prawie wszystkie podane przykłady pochodzą z RP. Jedyny nieapokryficzny przykład pochodzi z argumentów zamieszczonych przed tłumaczeniem psalmów w PsPuł:

Memor esto. Zaj wykłada sie sam, jakoby rzekł: sam pojdzi, jam cie słowo boże ciągnie (PsPuł 118d).

SStp zwraca uwagę na funkcję, którą jest wyjaśnianie. Zdzisława Krążyńska, pisząc o warstwach stylistycznych RP, także zauważyła tę grupę zdań i opisywała ją

3 Obecności formuł biblijnych w tekstach staropolskich apokryfów poświęcam osobne opracowanie. W przygotowaniu.

4 Omawiam je w artykule Komentarz biblijny w staropolskich apokryfach (w przygotowaniu).

5 W haśle JAKO SStp notuje znaczenie „10. wprowadza zdanie włączne 'to jest, mianowicie, na przykład”" i „11. wprowadza zdanie wtrącone”, ale w żadnym z nich nie notuje przykładów z jakoby rzekt. 
tak: „Podobieństwo wynika z porównania (retoryczny ikon). Wykładnik porównania pojawia się na początku drugiego zdania zawierającego wariantywną treść [...], wariantywną treść wprowadza zdanie metatekstowe" (Krążyńska 1995: 51). Pojawiła się tu już dodatkowa informacja - o wariantywnej treści. Tak jest często, jak np. tu:

Jest praw[d]a śmiara podać sie więcszemu przed Bogiem, oplwita podać sie mniejszemu. Jakoby rzekł: Tegodla sie tobie, mniejszemu, podaję, aby więcszy nie gardzili krzszczenia abo oprawy od mniejszych (RP 189/13-19).

Czasem ta sama treść jest przekazywana za pomocą innych słów, jak tu:

„Daj nam chleb nasz", to jest Jesukrysta, ktory jest chleb nasz, wiernych krześcijanow, a to nad chleb, czuż kromia chleba przyrodzonego, czuż potrzebnego, ku podpomożeniu ciała. Jakoby rzekł: Daj nam chleb, duszy i ciału (RP 277/20-278/4).

SPXVI także notuje osobno tę grupę zdań, wskazując znaczenie 'wyjaśniające treść wcześniejszego tekstu' i podając możliwe użycia 'w tłumaczeniach obcych wyrazów i zwrotów na język polski' i 'w etymologiach ludowych'. Notuje różne połączenia: "jakoby rzekł ( $a$. chciał, $a$. miał, $a$. raczył rzec), jakoby rzekąc, jakoby rzeczono było« (SPXVI, hasło JAKOBY).

Formuła jakoby rzekł jest kalką łacińskiej konstrukcji składniowej, dosłownym tłumaczeniem łacińskiego quasi dicat. Pojawia się w tekstach komentujących Biblię, np. u Piotra Comestora (1543) czy Grzegorza Wielkiego (Commentarii). Są to teksty autorów przytaczanych przez staropolskich apokryfistów i w nich również te łacińskie sformułowania pełnią funkcję wprowadzania wyjaśnień, jak np.:

Meliores vero greges et armenta, ut supra, electiora peccata luxuriae designantur. Quasi dicat: Et si graviter deliquit populus, arguendi non sumus; quia pro magnitudine criminis habet lamenta compuctionis (Commentarii: 425-426).

Wydaje się, że polscy apokryfiści stosują tę formułę niemal automatycznie, w sposób naturalny. Widać to w miejscach, w których łacińskie źródło wprowadza objaśnienie inną strukturą (np. przez hoc est), a po polsku oddano to przez jakoby rzekt (zob. np. SCh 48v/4-10).

Obecność formuły jakoby rzekł w staropolskich apokryfach pozwala na pewnego rodzaju wyróżnienie gatunkowe. Danuta Bieńkowska zauważyła, że „obecność stałych formul językowych $\mathrm{w}$ tekście biblijnym jest ściśle związana $\mathrm{z}$ istnieniem i wydzieleniem rodzajów i gatunków biblijnych" (Bieńkowska 2002: 105). Być może dlatego formuła jakoby rzekł nie występuje we wszystkich tekstach staropolskich apokryfów - pojawia się licznie w RP, SCh i ŻPJK, raz w EN, czyli głównie w teks- 
tach nastawionych na przedstawianie i komentowanie historii świętej, a nie rozwijanie „fabuł sensacyjnych” (w przeciwieństwie do HTK czy ŻSA). Należy to jednak wiązać nie tylko z przeznaczeniem i charakterem tekstu. Objaśnienia różnego typu (wprowadzane przez to jest, toczuż, toczu, czuż, rozumiej) pojawiają się bowiem we wszystkich tekstach. Ich geneza może być różna: mogły być glosą wciągniętą w tekst, objaśnieniem tłumaczonym wprost za którymś ze źródeł czy dopowiedzeniem (zob. np. Rojszczak-Robińska 2015; Ziółkowska 2020). Czym różnią się od nich objaśnienia wprowadzane przez jakoby rzekł? Formuła ta często wprowadza parafrazy - przetworzenia przytaczanych słów bohaterów. Zdolność do parafrazowania jest dziś uznawana za wyznacznik opanowania języka (EJO: 419). To, że w tekstach najbardziej zależnych od języka i tekstu łacińskiego (ŻSA i HTK) takich parafraz nie ma, zdaje się tę tezę potwierdzać. Ponadto fraza ta jest niezwykle popularna w Historia scholastica P. Comestora (quasi dicat / quasi diceret również wprowadza tam objaśnienia i w samej części dotyczącej wydarzeń ewangelicznych pojawia się ponad 50 razy). Zauważyć należy, że jest obecna przede wszystkim w tych polskich tekstach, dla których można wskazać HS jako jedno ze źródeł, tj. RP, SCh i ŻPJK.

Można na to spojrzeć jeszcze inaczej: omawiana fraza nie pojawia się (z jednym wyjątkiem) w tekstach zasadniczo opartych na jednym źródle - głównie narracyjnych lub opisowych, a nie teologicznych, czyli HTK, LL, ŻSA.

Analizowana konstrukcja może pełnić różne funkcje, m.in. objaśniać miejsca kontrowersyjne, które można w rozmaity sposób interpretować. Tak jest w wypadku jedynego miejsca w EN, w którym się pojawia:

I rzekli na ty słowa starszy z Żydow Jesusowi: „Widzielismy i wiemy dobrze, iżeś sie narodził z cudzołostwa, a w narodzeniu twym w Betlejem przez Heroda młodzianki jesteś pobił". Jakoby tako rzekł: Dla ciebie, gdyś się ty narodził, Herod wiele dzieci młodych jest pobił (EN 263v/17-264r/2).

W źródle nie ma tego objaśnienia.

Et scimus quod pater tuus Ioseph et mater tua Maria fugerunt in Eiptum propter quod honorem non haberunt in populo suo. Et in nativitate sua in Bethleem, per Herodem infantes interfecisti (EN 2.3).

W stosunku do wszystkich innych zachowanych odpisów EN tylko w redakcji z rękopisu Biblioteki Jagiellońskiej (zob. Izydorczyk, Wydra 2007: 13-14) w oskarżeniu Żydów pojawia się czasownik w 2 os. l. poj.: interfecisti ('zabiłeś'). W pozostałych zachowanych odpisach - jak twierdzą Wiesław Wydra i Zbigniew Izydorczyk - zarzut ten wygląda inaczej. Żydzi oskarżają Jezusa o to, że za jego przyczyną Herod zabił niemowlęta w Betlejem. Tak jest też w innych tekstach staropolskich, np.:

Prze ktoreż Herod, chcąc prawdę uczynić, szukał jego między dziećmi, a nie nalazł go. Wiele kazał pobić dzieciny, aby między jimi Jesusa zabił (SCh 81v/16-20). 
Jezus przedstawiany jest jako bezpośredni sprawca mordu lub tylko jego przyczyna. Takiej różnicy pisarz nie mógł nie zauważyć, więc ją skomentował:

The Polish translation rearranges the order of sentences in this chapter. The unusual directness of accusation that Jesus killed the children through Herod prompted the Polish translator to add an explanatory note, beginning "Jakoby tako rzekł” (Izydorczyk, Wydra 2007: 53).

Parafraza wprowadzona przez jakoby rzekł zmieniła perspektywę wypowiedzi oskarżycieli: jesteś pobił przez Heroda - dla ciebie Herod pobił i zabezpieczyła przed możliwością odczytania dosłownego. Podobny zabieg widać w tym fragmencie:

I rzekł Judaszewi Jesus: „Co działasz, działaj rychlej”. A to rzekł nie przykazując, ale jakoby $<$ z $>$ zjawie $<$ n $>$ ia. Rzekł jest: „Działaj”. Jakoby tako rzekł: Nie wątpi, bo rychło zdziałasz, co działać myślisz (SCh 31r/16-31v/2).

Słowa Jezusa wypowiedziane do Judasza podczas Ostatniej Wieczerzy (J 13,27: Quod facis, fac citius) zanotował tylko św. Jan. Ten fragment Ewangelii od początku budził wątpliwości. Polski tłumacz pragnął zapewne zabezpieczyć się przed możliwością następującej interpretacji: to Jezus nakazał Judaszowi zdradę, Judasz jedynie wykonywał polecenie. Taka interpretacja była popularna w literaturze współczesnej i młodopolskiej, ale pojawiła się już w gnostyckiej Ewangelii Judasza, odnalezionej w ostatnich latach (zob. np. Starowieyski 2006), czy średniowiecznych kazaniach Ferreriusza (zob. Ambrosini, Willis 1995). Staropolski autor wybrał najbardziej kontrowersyjny element - rozkaźnik działaj - i objaśnił, że ta wypowiedź to nie rozkaz. Najpierw wprost wyjaśnił intencję mówiącego: to rzekł nie przykazując, ale jako $<z>$ zjawie $<n>i a$, a potem dodatkowo użył parafrazy słów, pokazując, jak naprawdę należy je interpretować: Nie watpi, bo rychło zdziałasz, co działać myślisz. Podobnie objaśniał to jezuita, Menochiusz: „Nie są to słowa rozkazu albo upomnienia; ale sens jest, jakby rzekł: Chociażbym mógł, jednak nie przeszkadzam, nie opieram się, owszem nie dbam, ani się lękam; co do mnie, czyń coć się podoba" (cyt. za: BŁP).

Takich fragmentów, w których przy użyciu formuły jakoby rzekł apokryfiści objaśniali miejsca kłopotliwe, jest dużo więcej. Inną funkcją tej formuły jest wprowadzanie zaawansowanych treści teologicznych w miejsce prostych stwierdzeń, jak np.:

Tegodla zowieli ji Dawid Bogiem, kakoż jest syn jego? Jakoby rzekł: Wy mnimacie, aby mesjasz, czuż krystus, ktory ma przyć albo przychodzący jest, iżby był czysty i prawy człowiek. Tedy pirwej był Dawid niżli krystus, wszakoż tegodla Dawid nie był Bogiem. Tedy by Dawid zełgał? Bo też i prze krola Bog mowi. Podobniej, iże ocsowie są rzeczeni panowie synow niżli synowie ocsow (RP 416/3-12).

Komentowany jest fragment Ewangelii wg św. Mateusza (Mt 22,45), który musiał sprawiać problem. Polski autor przytoczył komentarz Comestora: 
Quasi dicat: Vos putatis Christum futurum purum hominem, ergo quando erat David, nondum erat Christus, nec ergo erat Dominus David. Mentitus est ergo David, et perperam locutus est. Potius enim patres sunt, et dicuntur domini filiorum, quam filii parentum (HS 132).

Notabene podobnie komentował to i Menochiusz: „Albowiem syna, a zwłaszcza jeszcze nienarodzonego, niema [!] zwyczaju nazywać panem, zwłaszcza gdy mówi ojciec i król zarazem. Pokazuje się więc, iż Chrystus jest więcej niż człowiekiem, i jest synem Bożym, i Bogiem prawdziwym” (cyt. za: BŁP).

Niektóre z parafraz wprowadzają objaśnienia teologiczne, wskazują na to, że w wypowiedzianych słowach spełniło się proroctwo, np.:

a też znamionał dobrze przyście Krystusowe i rzekł: „Z Nazareta może nieco dobrego być”. Jakoby rzekł: Juże sie pełni [iże się pełni], iże z Nazareta może być nieco dobrego (RP 214/16-21).

Często w tych objaśnieniach do Ewangelii (J 1,46 A Nazareth potest aliquid boni esse) pisarze wykorzystywali Historia scholastica P. Comestora, tak jest i w omawianym miejscu:

quasi diceret: Nunc tandem a Nazareth potest aliquid esse boni ( $\mathrm{HS}_{3} 6$ ),

a także w innych - nierzadko w miejscach paralelnych kilku polskich tekstów:

Tako pocznie k nim mowić, iże „dzisia popełni sie Pismo w waszych uszu”. Jakoby rzekł: Jaciem ten, o ktorem to pisano (RP 251/7-10);

A gdy zatworzył ony księgi, rzekł: „To Pismo dziś popełniło sie w uszach waszych”. Jakoby rzekł: Jam jest on, o ktorym to Pismo mowi (ŻPJK 24v/10-12).

Obaj pisarze podali za Comestorem ten komentarz do słów zachowanych w Ewangelii wg św. Łukasza (Łk 4,21). Co warto zauważyć, przejęli sam komentarz, a nie jego bezpośrednie otoczenie:

Et cum legisset in Isaia: Spiritus Domini super me, etc. (Isa. LXI), dixit, quia hodie completa est Scriptura haec in auribus vestris. Quasi dicat: Ego sum de quo scriptum est hoc, et omnes intendebant in eum (HS 42).

Widać, że cała formuła razem z treścią parafrazy czasem jest przytaczana za źródłem. Zdarza się, że za pomocą formuły jest wprowadzana treść dialogu przywołana w innym źródle kanonicznym (w sytuacji gdy ewangeliści podają różne wypowiedzi postaci, najczęściej Jezusa, a apokryfista ich nie skompilował), jak np.:

Miły Jesus, usłyszawszy imię Boże, natychmiast odpowiedział prawdę rzekąc: „Tyś powiedział, czuż co-ś pytał”. Jakoby rzekł: Jaciem syn Boży (RP 722/19-23). 
W tym miejscu do wypowiedzi Jezusa przytoczonej za Ewangelią wg św. Mateusza (Mt 26,64: Dicit illi Iesus: Tu dixisti) przyłączono dwa objaśnienia: jedno wprowadzone przez czuż, drugie wprowadzone przez jakoby rzekł. To drugie jednocześnie jest wariantem wypowiedzi zachowanym w Ewangelii wg św. Marka (Mk 14,62: Iesus autem dixit illi: Ego sum).

Duża część formuł jakoby rzekł pojawia się, gdy przytaczane są wypowiedzi złych postaci. Autorzy w ten sposób sprawiali, że neutralne wypowiedzi Judasza, Annasza, Kajfasza (i innych obecnych podczas procesu) przekazane przez ewangelistów stały się nacechowane emocjonalnie, bardziej agresywne czy wulgarne, jak np. w scenie przekazanej za J 18,22 (sic respondes pontifici):

dał wielki policzek Panu Jesukrystowi, rzekąc: „Tako odpowiadasz biskupowi?”. Jakoby rzekł: Ty lichy człowiecze, związany a jęty za tako wielki grzech, jako śmiesz mowić tako niepocześnie z tako wielkim biskupem? (SCh 56v/13-18).

We wszystkich tekstach widoczna jest chęć zintensyfikowania negatywnej oceny tych postaci (zob. m.in. Woźniak 2007; Rojszczak-Robińska 2012). Takie parafrazy pojawiają się nie tylko w stosunku do wypowiedzi przekazanych za źródłem kanonicznym, ale także w miejscach, do których źródeł dotąd nie wskazano, jak np. przy tej wypowiedzi Judasza:

„Tegodla obierzcie między sobą, co mi chcecie dać, a ja ji wam wydam w wasze ręce potajemnie przez wielkiej tłuszcze. Boć ja jako jego zwolenik wiem jego wszytki tajemnice”. Jakoby chciał rzec Judasz przeklęty: Takci mi ten Jesus mierziony i brzydki, jeśli jedno chcecie, wydamci ji wam za kielo pieniędzy (ŻPJK 50v/15-19).

Bardzo podobną wypowiedź Judasza zapisał też autor RP (zob. 510/14-511/1).

Co interesujące - wśród parafraz wprowadzających emocje widoczna jest ta sama tendencja, którą zaobserwowano w tekstach apokryficznych: potępiania i intensyfikacji negatywnej oceny Judasza wobec prób usprawiedliwiania Piłata (zob. Rojszczak-Robińska 2012). Wiele z parafraz wypowiedzi Piłata wprowadza bardzo emocjonalne, ludzkie i współczujące odpowiedzi, znacznie rozwijające suche komunikaty ewangeliczne. Przykładowo:

I rzekł im: „Owa człowiek”. Jakoby rzekł: O Żydowie, i wiedzieliście kiedy człowieka rownego temu tako zbitego i zbiczowanego, tako zmiotanego, zeplwanego i tako oszkaradzonego! O Żydowie, patrzcie, kakożem ji skarał! A przeto proszę was, aby męki, ktoreż cierzpiał i podjął, poruszyły was ku zlutowaniu, bo jest człowiek, a nie źwierzę (SCh 86v/13-87r/3).

Czasem można też zaobserwować próbę pokazania tego, że rzymska moralność i rzymskie prawo stoją wyżej niż żydowskie:

Wyszedł Piłat k nim przed dom i rzekł im: „Ktorą żałobę pokładacie przeciw temu człowieku?”. Jakoby rzekł: Nie jest obyczaj nijednego człowieka potępiać, ależ by miał 
na sie żałujące, ktorzyż by winowaćcą przez świadki przemogli, a krzywy mogłby sie odejmać swych win, oczyszczając sie. A przeto nie chcę tego przez winy tępić (SCh $73 \mathrm{r} / 16-73 \mathrm{v} / 5)$.

Bardzo podobne miejsce jest w RP (770/8-12) i objaśniałam je kiedyś tak:

Piłat stanowczo stwierdził, że nie chce sądzić niewinnego, podparł się przy tym obyczajem rzymskim. [...] Piłat - wedle pisarza RP - wyjaśnia: „Wiem, że jest niewinny. My, Rzymianie, nie skazujemy niewinnych na śmierć w przeciwieństwie do was, Żydów” (Rojszczak-Robińska 2012: 207).

Ta próba obrony Piłata wynika z apokryficznego charakteru tekstów i przyjętego stosunku do danych postaci, a nie z emocjonalności tych dzieł (tym należałoby wyjaśnić ich nieobecność w najbardziej emocjonalnych RD). Czytelnikom Biblii z pewnością brakowało tych informacji, dlatego apokryfy wyostrzyły cechy charakteru i sposób zachowania poszczególnych postaci - agresję arcykapłanów, perfidię Judasza, spokój Piłata, wyrozumiałość Jezusa, zapalczywość Piotra. Formuła jakoby rzekł idealnie się do tego nadawała. Pozwalała też nie dodawać nic do przekazu kanonicznych dialogów - pozostajemy wszak w sferze komentarza, nie opisywanych wydarzeń.

W tekstach (przede wszystkim w RP) można zaobserwować też grupę wtrętów metajęzykowych, objaśniających znaczenia słów trudnych, także wprowadzanych omawianą formułą, jak np.:

Przeto filatryja słuła, jakoby rzekł: Czci a chowaj albo pełni (RP 18o/6-8).

Jak widać, formuła jakoby rzekł w staropolskich tekstach apokryficznych była wykładnikiem różnych relacji. Za jej pomocą autor mógł wprowadzać objaśnienia metajęzykowe, alternatywną treść, komentować przytaczaną treść czy powodować zmianę nacechowania emocjonalnego przywołanej wypowiedzi.

W XVI w. omawiana formuła cieszyła się dużą popularnością. Może to być związane z reformacją i zwyczajem komentowania Biblii:

reformacja, zmuszając do dyskusji nad zagadnieniami abstrakcyjnymi (teologia, etyka, filozofia) uświadamiała potrzebę stworzenia języka, który by mógł być precyzyjnym narzędziem myśli (Rospond 1985: 109).

Formuła jakoby rzekł znakomicie się nadawała do precyzowania przekazywanych/tłumaczonych treści. W tym czasie obecna była nie tylko w dziełach religijnych, ale i świeckich, np. w Herbach rycerstwa polskiego:

Skoro go ujrzał czausz, bo z nim barzo rad przez tłumacza żartował, i tak giestom jego zawsze się uśmiał pohaniec, że przez całą drogę zażywaliśmy wielkiej rozkoszy, rzekł mu: Korkma, jakoby rzekł: nie bój się (Paprocki 1584/1858: 303). 
Jej funkcje są w większości zbieżne $\mathrm{z}$ tymi zaobserwowanymi w materiale starszym. Pojawiają się np. typowe wtręty metajęzykowe:

pod władzą Ojca Świętego była Panienka Kolumba imieniem; jakoby rzekł: Gołębica $\left(\mathrm{KorBa}^{6}\right)$;

od którego u Greków Libanotis nazwiska dostał; jakoby rzekł: Kadzidłów Ziele (KorBa).

Tak samo obecne są parafrazy „teologiczne”, objaśniające miejsca trudne i ważne, np. Piotr Skarga w ten sposób objaśniał znaczące kwestie, gdy próbował tłumaczyć sprawy państwowe za pomocą metafor teologicznych. Jest to wykorzystanie homiletyczne, odnoszące biblijną rzeczywistość do rzeczywistości właściwej odbiorcy tekstu:

„Z pilnością zachowajcie jedność ducha we związku pokoju [...]”. Jakoby rzekł: Trudno się macie rozrywać i wadzić, boście związani i spojeni, jako członki w jednym ciele, ktore się nigdy z sobą targać nie mogą; ktore jedna dusza ożywia i rządzi, od ktorej odstępować a jej nie słuchać, śmierć jest (SPXVI).

Pojawiają się też objaśnienia „emocjonalne”, oddające kwestie postaci (najczęściej Jezusa czy Boga Ojca) słowami bardziej ludzkimi, nacechowanymi emocjonalnie:

[Bóg] spytać go raczył: „Kaimie, a gdzie jest brat twoj?”. Jakoby rzekł: O, jako-ś go srogo zabił, upamiętaj się (SPXVI).

W XIX w. widać, że formuła jakoby rzekł jest wciąż żywa, ale wprowadza przede wszystkim parafrazę wyjaśniającą. Walenty Kuczborski w Wykładzie na lament Jeremiasza Proroka także używał jej, by wyjaśnić kwestie teologiczne, najczęściej skomentować słowa Jezusa lub proroków:

A tak się tém brzydzi prorok, że mówi, jakoby o niepodobnéj rzeczy, tak pytając; Zaż będą jadły niewiasty swój płód? jakoby rzekł: nie dopuścisz tego Panie, aby to jeszcze na na sprzyjść miało (1843: 206);

Pan Chrystus polecił, ale tylko Apostołom swoim i potomkom ich, mówiąc do nich: To czyńcie na moję pamiątkę, jakoby rzekł: bierzcie, błogosławcie, albo żegnajcie, to jest, poświęcajcie, a w tém słowie zamyka się ofiara (Łamcie i rozdawajcie) a w tém się zamyka communio (ibid.: 64).

W ostatnim przykładzie widać wyraźnie, że jakoby rzekł wprowadza wyjaśnienia najważniejszych słów - jak słowa przeistoczenia - a w zasadzie tłumaczy całą ideę komunii.

6 Cytaty z SPXVI i z KorBa podaję we własnej transkrypcji, sporządzonej wg zasad przyjętych w grancie, zob. przypis 1. 
Podobnie jest u Waleriana Serwatowskiego w Wykładzie Pisma Świętego Nowego Zakonu:

Do Zacheusza mówi: Dzisiaj zbawienie stało się temu domowi. Jakoby rzekł: Zbawicielem będąc wszedłem dziś w dóm twój, by w serce twe wkorzeniając poprawę życia i szlachetniejsze niebiańskie dążności zaszczepić w twej duszy zaród zbawienia. Dziś więc poczęło się zbawienie twoje, dziś oglądasz zbawiciela twego. A do ludu mówi Jezus: $i$ ón jest synem Abrahamowym. Jakoby rzekł: Jak twardego jesteście serca, gdy nie macie współczucia dla rodaka waszego. Pod pozorem patryotyzmu nienawidzicie tych, którzy z wami jednego są rodu (1844: 317).

W materiale współczesnym (NKJP) nie znajdziemy już w ogóle połączeń jakoby rzekł w tych funkcjach. Pozostało jedynie jakby rzekł w funkcji wprowadzania informacji uzupełniającej - wtrącenia, wskazywania możliwego autora wypowiedzi:

Trwają, bo, jakby rzekł bard, dróg ludzkość wytyczyła bez liku.

nakłonić damę do pochopności, jakby rzekł Paweł Głowacki [...].

$* * *$

Formuła jakoby rzekł (na tle innych formuł wprowadzających informacje dodatkowe) jest specyficzna - występuje prawie wyłącznie w dialogu i wprowadza parafrazę przytaczanej wypowiedzi bohatera biblijnego (czasem komentatora). Służy różnym celom: egzegezie teologicznej, a zwłaszcza wyjaśnieniu miejsc kontrowersyjnych, czasem uproszczeniu treści teologicznych czy przybliżeniu postaci Jezusa (zamiast przemów w parafrazie pojawiają się zwroty wprost do osób). Czasem parafraza może wpłynąć na nastawienie emocjonalne czytelnika (stawiając złego bohatera w jeszcze gorszym świetle). Nierzadko też przez jakoby rzekł wprowadzane są znaczenia słów, terminów obcych.

Na przykładzie zebranego materiału średniowiecznych apokryfów widać, że to w staropolszczyźnie wykształciła się formuła jakoby rzekł, służąca wprowadzaniu parafraz komentujących. Szczególne jej nagromadzenie widoczne jest w tym zbiorze tekstów. Choć była dość popularna w łacińskich pismach komentujących Biblię (np. patrystycznych czy w Historia scholastica P. Comestora), właściwie nieobecna jest w polskich tekstach wcześniejszych (z wyjątkiem jednego użycia w Psałterzu puławskim). W tekstach staropolskich apokryfów też widać rozróżnienie: używają jej autorzy tekstów niezależnych od języka łacińskiego, opartych na więcej niż jednym źródle i korzystający z HS. Widać też, że w tekstach staropolskich apokryfów formuła dopiero się kształtuje, nie jest jeszcze skostniała - najczęściej przyjmuje kształt jakoby rzekt, ale obecne są także warianty jakby (to) rzekł/rzekła/rzekli.

Formuła jakoby rzekł szczególnie popularna stała się w XVI-wiecznych tekstach religijnych - obecne są wówczas wszystkie jej funkcje zaobserwowane w materiale średniowiecznym. W polszczyźnie używana była do XIX w. 


\section{Skróty}

BŁP - Biblia łacińsko-polska; EN - Ewangelia Nikodema; HS - Historia scholastica; HTK Historyja Trzech Kroli; LL - List Lentulusa; PsPuł - Psałterz puławski; RD - Rozmyślania dominikańskie; RP - Rozmyślanie przemyskie; SCh - Sprawa chędoga o męce Pana Chrystusowej; ŻPJK - Żywot Pana Jezu Krysta Baltazara Opeca; ŻSA - Żywot świętej Anny

\section{Źródła}

apocrypha.amu.edu.pl, oprac. zespół pod kierownictwem D. Rojszczak-Robińskiej (tu: RP, RD, ŻPJK, SCh, EN, HTK).

Biblia łacińsko-polska, czyli Pismo Święte Starego i Nowego Testamentu. Podług textu łacińskiego Wulgaty, i przekładu polskiego x. Jakóba Wujka T.J. z komentarzem Menochiusza T.J. przełożonym na język polski; przedruk: Komorów 1997.

Comestor P., 1543, Historia scholastica, red. Lugduni (cyt. za: https://la.wikisource.org/ wiki/Historia_Scholastica).

CommentariI: Grzegorz Wielki, Commentarii in librum I Regum, księga V, [w:] J.P. Migne (red.), Patrologiae Latinae..., t. 79, Parisis 1849.

Ewangelia Nikodema, rkps Biblioteki Narodowej, sygn. 3040 IV.

Historyja Trzech Kroli, rkps Biblioteki Narodowej, sygn. 3040 IV.

KorBA: Elektroniczny Korpus Tekstów Polskich z XVII i XVIII w. (do 1772 r.), [on-line:] korba.edu.pl.

Kuczborski W., 1843, Wykład na lament Jeremiasza Proroka, Poznań.

NKJP: Narodowy Korpus Języka Polskiego, [on-line:] nkjp.pl.

Paprocki B., 1584/1858, Herby rycerstwa polskiego, wyd. K.J. Turowski, Kraków.

Psałterz puławski, [w:] Korpus tekstów staropolskich, [on-line:] https://ijp.pan.pl/publikacje -i-materialy/zasoby/korpus-tekstow-staropolskich.

Rozmyślania dominikańskie, rkps Biblioteki Klasztoru Karmelitanek Bosych w Krakowie, sygn. 287.

Rozmyślanie przemyskie, rkps Biblioteki Narodowej, sygn. 8024 III.

Serwatowski W., 1844, Wykład Pisma Świętego Nowego Zakonu, t. 2, Wiedeń.

Sprawa chędoga o męce Pana Chrystusowej, rkps Biblioteki Narodowej, sygn. 3040 IV.

\section{Literatura}

ADAмсZук M., 1980, Biblijno-apokryficzne narracje w literaturze staropolskiej do końca XVI wieku, „Filologia Polska” nr 19, Poznań.

Ambrosini M.L., Willis M., 1995, Tajne archiwa Watykanu, przeł. T. Szafrański, wyd. 2, Warszawa.

BAjerowa I., 1994, Swoistość języka religijnego i niektóre problemy jego skuteczności, „Łódzkie Studia Teologiczne" nr 3, s. 99-113.

BelCARzowa E., 1981-2001, Glosy polskie w łacińskich kazaniach średniowiecznych, „Prace Instytutu Języka Polskiego”, cz. 1, Wrocław 1981, cz. 2, Wrocław 1983, cz. 3, Kraków 1997, cz. 4, Kraków 2001. 
Bieńkowska D., 2002, Polski styl biblijny, Łódź.

EJO: K. Polański (red.), Encyklopedia językoznawstwa ogólnego, wyd. 3 bez zm., Wrocław Warszawa - Kraków 2003.

Izydorczy Z., Wydra W. (red.), 2007, A Gospel of Nicodemus Preserved in Poland. Evangelium Nicodemi in Polonia asservatum, "Corpus Christianorum. Series Apocryphorum. Instrumenta" 2, Turnhout.

KRĄŻYŃSKA Z., 1995, Warstwy stylistyczne „Rozmyślania przemyskiego”, [w:] Z. Krążyńska, Z. Zagórski (red.), Język polski - historia i współczesność: materiały z sesji naukowej zorganizowanej dla uczczenia 75. rocznicy powstania Uniwersytetu im. A. Mickiewicza (Poznań 4-5 maja 1994 r.), „Prace Komisji Językoznawczej - Poznańskie Towarzystwo Przyjaciół Nauk. Wydział Filologiczno-Filozoficzny”, t. 23, Poznań, s. 45-52.

LEŃCZuk M., 2013, Staropolskie przekazy kanonu Mszy Świętej: wariantywność leksykalna, „Studia Staropolskie. Series Nova”, t. 34, Warszawa.

PudA-Blokesz M., 2009, Formuły i formuliczność jako wyznaczniki stylu biblijnego, [w:] S. Koziara, W. Przyczyna (red.), Polszczyzna biblijna - między tradycja a współczesnością, t. 1, „Teolingwistyka”, t. 6, Tarnów, s. 35-52.

Rojszczak-Robińska D., 2012, Jak pisano Rozmyślanie przemyskie, Poznań.

Rojszczak-RobıŃska D., 2014, O powiązaniu analizy stylistycznej i źródłoznawczej. Znad Rozmyślania przemyskiego, „Slavia Occidentalis” 71/1, s. 123-144.

Rojszczak-RoвıŃska D., 2015, Łacińskie źródła Rozmyślania przemyskiego. Pytania, problemy perspektywy, [w:] T. Mika, D. Rojszczak-Robińska, O. Stramczewska (red.), Jak badać teksty staropolskie, „Staropolskie Spotkania Językoznawcze”, t. 1, Poznań, s. 135-172.

Rospond S., 1985, Kościół w dziejach języka polskiego, „Prace Językoznawcze - Polska Akademia Nauk", t. 103, Wrocław.

SовсZукоша J., 2001, Myśl o języku w komentarzu biblijnym ks. Jakuba Wujka, „Prace Naukowe Uniwersytetu Śląskiego w Katowicach", nr 1987, Katowice.

SPXVI: Słownik polszczyzny XVI wieku, t. I-IV, red. komitet redakcyjny, t. V-XVII, red. M.R. Mayenowa, t. XVIII-XXXIV, red. F. Pepłowski, t. XXXV-XXXVI, red. K. Mrowcewicz, P. Potoniec, Wrocław - Warszawa - Kraków 1966-2012.

SStp: S. Urbańczyk (red.), Słownik staropolski, t. I-XI, Wrocław 1953-2002 (od t. X, Z. 4 - Kraków).

Starowieyski M., 2006, Judasz: historia, legenda, mity, Poznań.

StAROWIEYski M., 2015, Barwny świat apokryfów, wyd. 3 popr. i uzup., Poznań.

WoźNIAK E., 2007, Ofiary i krzywdziciele: studium postaci w przedtrydenckim piśmiennictwie pasyjnym: analiza językoznawcza, „Rozprawy Habilitacyjne Uniwersytetu Łódzkiego", Łódź.

ZıóŁKowsKa O., 2020, O wieloznaczności i funkcjonalności terminu dopowiedzenie. Na przykładzie nowotestamentalnych apokryfów staropolskich, „Biuletyn Polskiego Towarzystwa Językoznawczego" LIIVI, s. 281-292, [on-line:] https://biuletynptj.com/resources/html/ article/details?id=212318\&language $=$ pl. 


\section{On Shaping the jakoby rzekł Formula in the Old Polish Language Summary}

In the 15th century, a commenting formula: jakoby rzekł appeared in Polish as a calque of the Latin: quasi dicat. Its accumulation can be seen in those old Polish apocrypha that are multi-source and focused on theology, not just events. The jakoby rzekł formula occurs almost exclusively in dialogue and introduces a paraphrase of the quoted statement of a Biblical character. It serves various purposes: theological exegesis, especially explaining controversial issues and, sometimes, simplifying theological content, making the figure of Jesus more familiar, or changing the emotional attitude of the reader; also, it introduces explanations of foreign terms. The formula: jakoby rzekt became especially popular in the 16th-century religious texts. They include all functions of the formula noticed in the medieval materials. The formula was used in the Polish language until the 19th century. 